\title{
AN EMPIRICAL STUDY ON THE MOTIVATION OF CHOOSING FAIR VALUE MEASUREMENT MODEL IN INVESTMENT PROPERTY
}

\author{
Aiyuan Shen \\ Panyapiwat Institute of Management, Nonthaburi, Thailand
}

This paper selects all non-ST listed companies in the A-share market with investment properties in the time period from 2015 to 2019 as the initial research sample and employs a binary logistic regression model to empirically examine the specific motivations of companies' management in choosing the fair value measurement model. Our results show that the level of enterprise fair value measurement has a significant positive impact on the increase in net profit, the improvement in the ability of debt financing, the increase in total assets, the increase in the level of executive compensation and the increase in enterprise value. However, it also enhances the level of enterprise earnings management and leads to an increase in speculations by enterprise executives. In the meantime, the higher the level of fair value measurement of investment properties, the greater the fluctuations in profit, total assets and debt financing. This indicates that the adoption of the fair value measurement model for investment properties will increase the instability of profit, total assets and debt financing of enterprises. The majority of enterprises currently adopt the fair value measurement model in relation to the listed investment properties for opportunistic motives, as a way of presenting an improved quality of enterprises' financial disclosure to both outside investors and the market overall, while catering for market developments and external regulation.

Keywords: investment property; cost model; fair value model; profit; total assets; debt financing

\section{Introduction}

Among the newly issued accounting standards system for enterprises, the standard on investment properties has gained a lot of attention. As per the provisions of this new
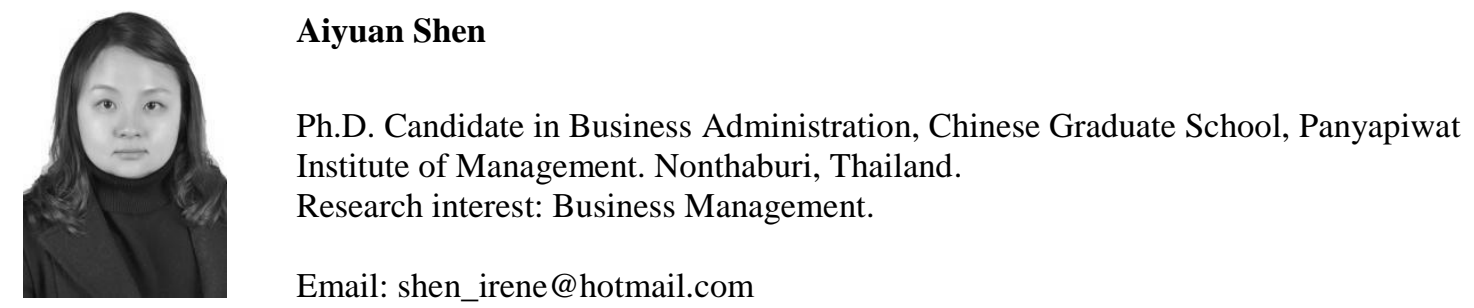
standard, an enterprise can adopt either the cost model, or the fair value model in the subsequent measurement of investment properties. As China's real estate market continues to be highly active these days, the fair value of investment properties is mostly higher than their carrying value. If an enterprise adopts the fair value model for the subsequent measurement of its investment properties, it will lead to a substantial increase in profit and a corresponding increase in assets and owners' equity.

At the beginning of the implementation of the investment property standard back in 2007, there were only 18 listed companies adopting the fair value measurement model for investment in real estate in the country, thus accounting for $1.12 \%$.

By 2015, 66 enterprises, with the ratio of 2.84\%, had adopted the fair value measurement model for investment in real estate. In 2016, 2017, 2018 and 2019, there were $71,78,85$ and 91 enterprises, with the ratios of $2.33 \%, 2.34 \%, 2.37 \%$ and $2.42 \%$ respectively, all adopting the fair value measurement model for investment in real estate. It is evident that most enterprises are reluctant to choose the fair value measurement model despite the overall improvement in performance that it can bring to business operations. Thus, a question arises: Why are most companies so reluctant to choose the fair value measurement model and what are the factors that influence companies in making their choice of measurement model?

Regarding these questions, the existing literature provides different answers from different perspectives. Ball (2006) argued that although specific conditions need to be met for the adoption of the fair value measurement models, these models would be favored for the more relevant accounting information they could provide. In contrast, Qiang (2007) argued that the cost measurement model was more effective under a contractual view on the accounting figures as it reduces the agency costs arising from creditor protection, political sensitivity, taxation and litigation.

Quagli and Avallone (2010) found that information asymmetry, contractual efficiency and opportunistic behaviour of executives could explain the choice of fair value measurement models for investment property in a study based on the listed real estate companies in European countries that were first-time adopters of the International Financial Reporting Standards.

Liu Yongze and Ma Yan (2011) argued that the imperfect market conditions, strict standard restrictions, lack of relevant guidelines and difficulties in changing accounting measurement concepts were the main reasons why the fair value measurement model was facing difficulties in its application to investment properties.

Dai et al (2011) took Beijing North Star as an example and analysed the determinants of an enterprise's choice between the cost measurement model and the fair value measurement model for investment properties. Their results showed that the main reasons for Beijing North Star to adopt the cost model in its A-share annual report and the fair value model in its H-share annual report were as follows: (1) differences in accounting standards between the two places; (2) differences in the regulatory authorities of the two places on fair value accounting; (3) differences in the disclosure of information on investment properties in the two places; and (4) differences in the maturity of capital markets and the rationality of investors in the two places.

Liu Yajun and Hou Xiaohong (2012) found that fewer companies would adopt the fair value model for subsequent measurement of investment properties due to the higher initial cost of adopting the fair value model, which may increase the income tax expense and cash 


\section{AN EMPIRICAL STUDY ON THE MOTIVATION}

outflow of companies and cause fluctuations in enterprise surplus and profitability of dividends.

While most of the current literature employs normative analysis and case studies to analyze the factors influencing the choice of subsequent measurement models for investment properties, very little literature employs empirical analysis to verify the determinants of the choice of subsequent measurement models for investment properties.

Although Chen Ying (2010) had empirically verified the factors influencing enterprises' choice of fair value measurement model for investment properties in terms of reducing information asymmetry and improving management efficiency, his test was only on listed real estate enterprises and the findings could not be thus generalized. As there were companies in other industries that adopted the fair value model for the subsequent measurement of investment properties, and as the difference between the numbers of its regression sample adopting the cost model and the fair value model was large, it decreased the persuasiveness of their findings.

On this basis, this paper selects listed companies that have adopted the fair value measurement model for investment properties during 2015-2019 as the initial research sample for the empirical analysis. We have tested the specific motivations behind the choice of the fair value measurement model in investment properties from two perspectives, which are the opportunistic choice of fair value model by company's executives and the provision of higher quality in accounting information.

\section{Investigation and Analysis of the Value Relevance and Reliability of Fair Value in Investment Properties}

Based on the fact that the number of enterprises currently employing the fair value measurement model for investment properties in China is still relatively small, the use of the fair value measurement model for investment properties is not yet fully mature at the current market. Based on the problem-oriented dimension, the author first employs a survey analysis to obtain the specific perceptions and evaluations from the now operating domestic enterprises on the fair value measurement model in investment properties and the relevance and reliability of the value of such models, before proceeding to the analysis of motivations for choosing the investment fair value measurement model.

The survey has been conducted in the form of electronic questionnaires, which were distributed to companies/institutes/associations in a targeted and random way. The totals of 310 questionnaires were distributed to professionals, and 305 questionnaires were subsequently returned. Regarding the data collected the questionnaires with contradictory answers, missing or unanswered items were excluded. Thus, 302 valid samples were retained, with the effective rate of $97.42 \%$.

The regression results obtained from a binary logistic regression model with whether or not the choice of a fair value measurement model by the enterprise was supported as the dependent variable and the findings on value relevance and reliability as the independent variables are shown in Tab. 1.

Whereby the estimated coefficient of value relevance is $0.804(p=0.000<0.001)$. This implies that the value relevance of the fair value of investment properties has a positive impact on whether or not the choice of a fair value measurement model is supported by the enterprise. 
The estimated reliability coefficient was $0.331(\mathrm{p}=0.013<0.05)$ (Tab. 1), which implies that the reliability of the fair value in investment properties has a significant positive impact on whether or not the choice of fair value measurement model is supported by the enterprise. It indicates that the higher the relevance and the reliability of fair value in investment properties is, the more professionals would support other enterprises to choose the fair value measurement model.

Table 1 - Results of Binary Logistics Regressions on Whether to Support the Fair Value Measurement Model in Investment Properties

(made by the author)

\begin{tabular}{|l|c|c|c|c|c|}
\hline & B & $\begin{array}{c}\text { Standard } \\
\text { Deviation }\end{array}$ & Wald & $\begin{array}{c}\text { Degrees of } \\
\text { Freedom }\end{array}$ & $\begin{array}{c}\text { Statistical } \\
\text { Significance }\end{array}$ \\
\hline Value Relevance & 0.804 & 0.129 & 38.755 & 1 & 0 \\
\hline Reliability & 0.331 & 0.132 & 6.232 & 1 & 0.013 \\
\hline Constants & -3.836 & 0.529 & 52.607 & 1 & 0 \\
\hline Omnibus Test and & \multicolumn{5}{|c|}{$57.85^{* *}(0.000)$} \\
\hline $\begin{array}{l}\text { Hosmer } \\
\text { Lemeshow Test }\end{array}$ & \multicolumn{5}{|c|}{$535.965(0.651)$} \\
\hline 2 Log likelihood & \multicolumn{5}{|c|}{0.201} \\
\hline Cox \& Snell R2 & \multicolumn{5}{|c|}{0.273} \\
\hline NagelkerkeR2 & \multicolumn{5}{|c|}{} \\
\hline
\end{tabular}

In our survey on the relevance and reliability of the fair value in investment properties of China, we have adopted a joint participation of financial officers of the listed companies and other professionals in the field of finance and obtained that the professionals that were currently familiar with the relevance and reliability of the fair value of investment property. Interestingly, they didn't not give it a high rating.

Through further linear regression analysis, we have observed that the decision whether professionals support enterprises in adopting the fair value measurement model in investment properties was influenced by the value relevance and reliability of fair value. This indicates that the higher value relevance and reliability of fair value might lead enterprises to choosing such a measurement model.

However, given the current situation that the value relevance and reliability of the fair value disclosed by the listed companies in China are not high, the number of enterprises choosing the investment fair value measurement model is increasing annually. Thus, it is reasonable to analyze the motivation of enterprises themselves when they are choosing the fair value measurement model for investment purposes.

\section{Theoretical Analysis and Study Hypothesis}

Many scholars currently believe there is a strong correlation between changes in the measurement model of an enterprise's investment property and the quality of its financial information. Fargher \& Zhang (2014) argued that permitting management to exercise more discretion in the fair value measurement could have a negative impact on the quality of financial reporting. 


\section{AN EMPIRICAL STUDY ON THE MOTIVATION}

However, some scholars believe that the mandatory requirement for disclosure on fair value under the application of the fair value measurement could enhance investors' judgement on unpredictable inputs. Therefore, some enterprises would choose to use the fair value measurement model in order to improve the quality of information disclosure.

Eliwa et al. (2016) argued that the implementation of the FASB fair value measurement standard (ASC 820-10) could improve the quality of financial reporting. Particularly, when measuring unobservable inputs, it could enhance information disclosure.

At the same time, Yinghe (2018) argued that when enterprises measure special assets of the enterprise by using the fair value, it would affect the quality of financial information. Meanwhile, some scholars believe that application of fair value measurement can reduce information asymmetry among investors most effectively, and this, in turn, may have an effect on the risk return of enterprises. Zhou Xiaohui (2015) pointed out that information asymmetry prior to the adoption of the fair value measurement model in investment properties plays a significant role in the adoption of the fair value measurement model by listed companies in subsequent measurements.

Therefore, it is inevitable for domestic enterprises to choose the fair value measurement model under the premises of assuring the relevance and the reliability of financial information. On this basis we propose the following hypothesis 1.

H1. Enterprises with poorer quality of financial information prior to the adoption of the fair value measurement model would be more likely to adopt the fair value measurement model for their investment properties.

Based on the existing study on the motivation behind the selection of the fair value measurement model, it can be seen that the current motivation for enterprises when selecting the fair value measurement model for investment properties is relatively diverse and complex. The current capital market has a certain regulatory role in the profit and loss situation of the listed companies, as the State Assets Supervision and Administration Commission (SASAC) has certain requirements in terms of the assets and liability ratio of

the listed companies, and there would be operational risks for the listed companies that do not meet these requirements of the SASAC.

Thus, some of the investment property enterprises choose the fair value measurement model in order to improve their operating performance and reduce the debt ratio. Wang Fusheng \& Cheng Fu (2014) found that executives tend to choose the fair value measurement model in investment properties to improve the performance based on empirical analysis. By analyzing the correlation between fair value and financial indicators, Walid \& Bondar (2017) verified that the fair value measurement model is the most correlated with the financial indicators in the income statement, namely, with net profit, which is basically the measure of the overall loss and profitability of enterprises.

It could be seen that the financial profit and loss management of enterprises is a major motivation for the adoption of the fair value measurement model. It is clear that most of the formulas used in the fair value measurement model are positively correlated with enterprises' losses. Also, based on the analysis of capital market regulation, enterprises with significant losses have stronger incentives to avoid market regulation and tend to increase their current earnings directly without increasing their tax burden, which can be achieved by investment properties under the fair value measurement model. On this basis, this paper proposes the following hypothesis 2 . 
H2. Enterprises with greater losses prior to choosing the fair value measurement model would be more likely to choose this model in relation to their investment properties.

Some enterprises are currently adopting the use of fair value to convey the liquidation value of assets to creditors. From the standpoint of the enterprise debt financing, the debt ratio is used as a measure of scaling its enterprise debt financing. The higher the debt ratio of an enterprise, the larger the enterprise's financing. And also, the higher the enterprise's financing, the higher the enterprise's ability to raise financing debt. Some enterprises are currently transferring their debts in the form of bonds to other investment entities. To meet the demand for bond issues, investment property enterprises must improve their strength and solvency to satisfy the needs of investors, and most of them have started to adopt the fair value measurement model which shows a strong link between the application of the fair value measurement models and the debt financing needs of enterprises.

Wang F. \& Cheng F. (2014) took a sample of Chinese listed companies that chose the fair value model to measure investment properties (in the time period from 2007 to 2012) and obtained the results based on a binary logistic regression model that the probability of choosing the fair value model to measure investment assets was positively related to the debt ratio of these enterprises.

While some scholars argued that adoption of the fair value measurement models can increase the possibility of debt financing for enterprises, Aleszczyk et al. (2020), on the other hand, indicated that application of the fair value measurement models could facilitate debt financing effectively, thus verifying that the fair value adjustment of tangible assets is associated with the issuance of a large number of new bonds by the acquiring enterprise within three years from the transaction as well as with the issuance of cheaper, secured longterm debt and a greater probability of having balance sheet covenants. Therefore, this paper proposes hypotheses 3 and 4 as follows:

H3. The long-term debt ratio is positively correlated with the probability of a fair value measurement.

H4. Debt maturity is positively or negatively correlated with the probability of a fair value option.

The investment property rate is part of the enterprise's special assets. Hence, change in the measurement model of investment premises has a clear correlation with the enterprise capital. Ashwag Dignah et al. (2017) pointed out that data in the fair value hierarchy actually contains three hierarchies, including measurement error, information asymmetry, and information risk. When the inputs of the third hierarchy of fair value are used, financial information under the fair value measurement model will be significantly related to the capital of the enterprise.

Therefore, it is proposed that financial indicators can "improve" the relative value and growth of an enterprise effectively. On this basis, this paper proposes that the more an enterprise highlights its growth, the more likely it is to adopt a fair value measurement model for its investment properties, which leads us to hypothesis 5 as follows:

H5. Enterprises with a lower growth rate of the total assets prior to adopting the fair value measurement model for investment properties are more likely to choose this model.

Most enterprises at present have a clear distinction between executives and owners, with the shareholders giving control to the executives by delegating management functions and responsibilities to them. Meanwhile, compensation of executives is closely correlated with the company's profitability in the context of the principal-agent process: the higher the 


\section{AN EMPIRICAL STUDY ON THE MOTIVATION}

profitability of the enterprise, the better the performance of executives will be, hence, the higher compensation they will receive. Therefore, in order to obtain higher levels of compensation, most enterprise executives will need to manage uncertain earnings, while the uncertainty of fair value makes the book earnings of the enterprise more manipulable. Hou Xiaohong and Guo Ya (2013) argued that under the principal-agent model, adoption of the fair value measurement model had a direct relationship with the executives' compensation management.

It is also commonly considered that since compensation of executives is directly related to performance, executives are more inclined to manipulate profits in investment properties by adopting the fair value measurement model in order to increase their personal earnings. Therefore, the hypothesis about the motivation to increase executive remuneration is proposed below.

Also, under the principal-agent model, where profits of an enterprise are related to the incentives of the executives, the latter would resort to earnings management activities in order to make book performance more desirable, while the uncertainty of the fair value, and the margin it has for manipulation, leaves the executives with the opportunities for such a manipulation. On this basis, this paper proposes the following hypothesis 7 .

H7. The fair value measurement model in investment properties is positively correlated with the degree of executive earnings management.

Although asset returns under the fair value measurement model are more volatile than those under historical cost, stock prices would not be affected by such volatility and it would not reflect large fluctuations in incremental amounts. Whereas the fair value measurement model has a significant predictive nature to market regulated capital irregularities, such predictive nature reduces the risk of potential market regulation of stock prices and therefore the fair value measurement model has a significant effect in increasing the non-volatility of stock prices. It can be seen that there are the actual reasons for enterprises to adopt the fair value measurement model to increase their stock prices. On this basis, this paper proposes hypothesis 8 .

H8. Prior to the adoption of the fair value measurement model, enterprises with lower stock prices are more likely to choose the fair value measurement model for their investment properties.

\section{Study Design}

\section{Dependent Variables}

Based on the above calculation of the valuation model for the fair value measurement model, a more realistic modification was made to the relevant theoretical formula, and then the investment assets of the sample enterprises were measured with the final adoption of the fair value measurement model as the dependent variable, whereby the adoption of the fair value measurement model was given the value of 1 and the adoption of the cost measurement model was given the value of 0 .

\section{Independent Variables}

Based on the current financial information disclosure about the situation of enterprises, the quality of financial information is measured by the assessment ratings of financial information disclosure, and the higher the assessment rating of financial information 
disclosure is, the higher the quality of financial information will be. Meanwhile, net profit is used to measure the profit and loss of the enterprise's performance.

However, as the unit of measurement of net profit is too large, to circumvent the unit error of net profit, the standardized net profit of $\mathrm{z}$ is further chosen as the measurement indicator, and when $\mathrm{z}$ (net profit) is higher, it means that the enterprise's profitability is better and the loss is less possible, and when $\mathrm{z}$ (net profit) is less than 0 , it means that the enterprise has a loss situation.

Table 2 - Variables Description Table

(made by the author)

\begin{tabular}{|c|c|c|c|}
\hline $\begin{array}{l}\text { Abbreviation } \\
\text { Code }\end{array}$ & Variables & Measurement Indicators & Definition and Calculation \\
\hline FVEM & $\begin{array}{c}\text { Fair Value } \\
\text { Measurement Model }\end{array}$ & $\begin{array}{c}\text { Whether to choose the } \\
\text { fair value measurement } \\
\text { model }\end{array}$ & $\begin{array}{c}\text { Adoption of the fair value measurement } \\
\text { model }=1 \text { and non-adoption of the fair value } \\
\text { measurement model }=0 \text {. }\end{array}$ \\
\hline QOFI & $\begin{array}{l}\text { Quality of Financial } \\
\text { Information }\end{array}$ & $\begin{array}{c}\text { Financial Disclosure } \\
\text { Rating }\end{array}$ & 1=Fail, $2=$ Pass, 3=Good, 4=Excellent. \\
\hline PALS & $\begin{array}{c}\text { Profits and Losses } \\
\text { Situation }\end{array}$ & Net Profit & z-score（Net Profit / Total Assets） \\
\hline DFDF & $\begin{array}{l}\text { Debt Financing } \\
\text { Demand }\end{array}$ & Long-term Debt Ratio & Long-term Debt/Total Debt \\
\hline ATFD & $\begin{array}{l}\text { Ability to Finance } \\
\text { Debt }\end{array}$ & Loan Maturity & Term calculation in the unit of year \\
\hline ECST & Enterprise Growth & $\begin{array}{c}\text { Growth Rate of Total } \\
\text { Assets }\end{array}$ & $\begin{array}{l}\text { (Total Assets at the End of the Year - Total } \\
\text { Assets at the Beginning of the Year)/Total } \\
\text { Assets at the Beginning of the Year }\end{array}$ \\
\hline ECGR & $\begin{array}{l}\text { Executive } \\
\text { Compensation Growth } \\
\text { Ratio }\end{array}$ & $\begin{array}{l}\text { Growth Rate of } \\
\text { Total Executive } \\
\text { Compensation }\end{array}$ & $\begin{array}{l}\text { (Total Executive Compensation } \\
\text { Total Executive Compensation of the } \\
\text { Previous Year) / Total Executive } \\
\text { Compensation of the Previous Year }\end{array}$ \\
\hline EMTM & $\begin{array}{l}\text { Earnings } \\
\text { Management } \\
\text { Tendency } \\
\end{array}$ & $\begin{array}{l}\text { Discretionary } \\
\text { Accruals }\end{array}$ & The Modified JONES Model \\
\hline POTS & $\begin{array}{|ll|}\text { Ptock } & \text { Price of the } \\
\end{array}$ & & Average Annual Stock Price \\
\hline
\end{tabular}

In terms of debt financing needs, the long-term debt ratio is used as a measurement indicator, with higher long-term debt ratios indicating greater debt financing needs. In terms of the ability to raise financing debt, loan maturity is used as a measurement indicator, with a longer average loan maturity indicating a higher ability to raise financing debt.

Besides for the growth aspect of the enterprise, the growth rate of the total assets is used as the evaluation indicator. And when the growth rate of the enterprise's total assets is higher, the growth of the enterprise is stronger. In terms of the hypothesis about the executive incentive aspect of the enterprise, the growth rate of the total executive compensation is used as a measure of the growth of executive compensation with regard to the tendency to manage earnings. 


\section{AN EMPIRICAL STUDY ON THE MOTIVATION}

Based on the modified JONES model to calculate discretionary accruals, when the degree of discretionary accruals is higher, the executives' earnings management activities become more frequent. Stock price is used as a measure of the face value of the stock.

\section{Study Model}

In view of the study hypothesis that the dependent variable is the fair value measurement model, this paper establishes a binary logistic regression model:

$$
\begin{aligned}
& \ln \left(\mathrm{p}_{F V E M-1} / 1-\mathrm{p}_{\text {FVEM-1 }}\right)=\partial_{0}+\partial_{1} Q O F I+\partial_{2} P A L S+\partial_{3} D F D F+\partial_{4} A T F D+\partial_{5} E C S T \\
& +\partial_{6} E C G R+\partial_{7} E M T M+\partial_{8} P O T S .
\end{aligned}
$$

\section{Sample Selection and Data Sources}

This paper selects all the non-ST listed companies in the A-share market that owned investment properties in the years 2015 to 2019 as the initial study sample. As the data of the indicators involved in the empirical analysis in this chapter we will be using the data of the previous year; the data concerning the independent and the control variables involved in the subsequent empirical part are the data of the year before the application of the fair value measurement model for investment properties.

For example, whether the fair value measurement model of 2015 was chosen or not, the data corresponding to the explanatory variables are observations as of 2014. In further analysis, the statistical analysis involving the motivation for choosing the fair value measurement model for investment properties corresponds to the data observed in practice during the period of 2015-2019.

Therefore, based on the following conditions, the following invalid sample part was excluded:

(1) companies without investment property items/total in the years of 2014-2019;

(2) companies with zero financial accounting for investment property in the years of 2014-2019;

(3) companies with suspended or terminated listing in the years of 2014-2019;

(4) companies newly listed in the years of 2014-2019; and

(5) companies with missing indicators in the years of 2014-2019.

The final calculations were made for the total of 4,463 panel data units, of which, the total of 389 were identified using the fair value measurement model. The data used in this paper are from the CSMAR database and the RESSET database.

\section{Empirical Analysis}

\section{Descriptive Statistical Analysis}

The sample data was firstly subject to descriptive statistical analysis in terms of the quality of financial information, profit and loss situation, debt financing demands, the ability to raise debt financing, capital structure, executive compensation growth ratio, tendency of earnings management, and stock price situation.

As shown in Tab. 3, the average value of the ratings of the financial information disclosure of the sample enterprises is 1.9 and the standard deviation is 0.637 . 
This indicates that the current ratings of the financial information disclosure in the most of the sample enterprises are low and tend to be substandard. The average value of profit and loss for the current sample of enterprises is 0 , with the standard deviation of 1 .

Thus, it can be seen that the profit and loss situation of most enterprises under analysis is at the stage when profit and loss are equal. The current average values of debt financing demand and financing duration of the enterprises are 0.166678 and 1.699812 respectively, with the standard deviations of 0.1730960 and 1.9738610 .

Combining the maximum and the minimum values, we can see that there is a large gap between the debt financing demand and the ability to finance among the sample enterprises. In addition, taking into account the current growth rates of the total assets, executive compensation growth ratios, the tendency of earnings management and the stock prices of the sample enterprises, there are significant differences in capital outcomes as well as in executive incentives and stock prices between the sampled enterprises.

\section{Table 3 - Descriptive Statistical Analysis} (made by the author)

\begin{tabular}{|c|c|c|c|c|c|}
\hline Variables & $\mathrm{N}$ & Min. Value & Max. Value & $\begin{array}{c}\text { Average } \\
\text { Value }\end{array}$ & $\begin{array}{c}\text { Standard } \\
\text { Deviation }\end{array}$ \\
\hline QOFI & 4463 & 1 & 4 & 1.90 & 0.637 \\
\hline PALS & 4463 & -4.79947 & 19.37282 & 0 & 1 \\
\hline DFDF & 4463 & 0 & 0.9625 & 0.166678 & 0.1730960 \\
\hline ATFD & 4463 & 0.1600 & 36.0000 & 1.699812 & 1.9738610 \\
\hline ECST & 4463 & -0.7253 & 47.9275 & 0.272310 & 1.1717407 \\
\hline ECGR & 4463 & -1.0000 & 64.3773 & 0.116020 & 1.1294565 \\
\hline EMTM & 4463 & -1.7428 & 15.4924 & 0.000975 & 0.2741697 \\
\hline POTS & 4463 & 0.6380 & 186.0000 & 11.695790 & 9.0183186 \\
\hline
\end{tabular}

Upon further comparison on the quality of financial information, profit and loss, debt financing demands, the ability to raise debt financing, capital structure, executive compensation growth ratio, tendency of earnings management and stock price under the fair value measurement model and historical cost measurement model of the investment properties, the results combined with the average and variance tests are shown in Tab. 4.

The quality of financial information, profit and loss, the ability to raise debt financing, capital structure, executive compensation growth ratio and stock price before the application of the historical cost measurement model were all higher than those before the application of the fair value measurement model, while the debt financing demands of the enterprises before the application of the fair value measurement model were significantly higher than those with the application of the historical cost measurement model.

However, there was no significant difference in the tendency of earnings management before the adoption of the historical cost model and the fair value model, which indicates that there would be no significant impact on the tendency of earnings management regardless of the measurement model adopted in investment properties. 


\section{AN EMPIRICAL STUDY ON THE MOTIVATION}

Table 4 - Test Results for Differences in Interpretative Variables in the Two Measurement Models

(made by the author)

\begin{tabular}{|c|c|c|c|}
\hline FVEM & $\begin{array}{c}\text { Historical Cost Measurement } \\
\text { Model }\end{array}$ & $\begin{array}{c}\text { Fair Value Measurement } \\
\text { Model }\end{array}$ & $\mathrm{F}$ \\
\hline QOFI & 1.93 & 1.64 & $74.808^{* *}$ \\
\hline PALS & 0.0433967 & -0.4544942 & $89.778^{* *}$ \\
\hline DFDF & 0.139649 & 0.449751 & $1530.277^{* *}$ \\
\hline ATFD & 1.757428 & 1.096401 & $40.174^{* *}$ \\
\hline ECST & 0.306871 & -0.089651 & $41.029^{* *}$ \\
\hline ECGR & 0.157943 & -0.323031 & $65.323^{* *}$ \\
\hline EMTM & 0.0008 & 0.002803 & 0.019 \\
\hline POTS & 11.910089 & 9.45144 & $26.544^{* *}$ \\
\hline
\end{tabular}

\section{Correlation Analysis}

Tab. 5 shows that there is a significant negative correlation between the adoption of the fair value measurement model and the quality of financial information, profit and loss, the ability to raise debt financing, capital structure, growth in executive compensation and stock price $(\mathrm{p}<0.05)$, and a significant positive correlation with the demand for debt financing ( $\mathrm{p}$ $<0.01)$, but no significant correlation with the tendency of earnings management $(\mathrm{p}>0.05)$.

Table 5 - Correlation Analysis of the Variables

(made by the author)

\begin{tabular}{|c|c|c|c|c|c|c|c|c|c|}
\hline & FVEM & QOFI & PALS & DFDF & ECST & EMTM & ECGR & POTS & ATFD \\
\hline FVEM & 1 & & & & & & & & \\
\hline QOFI & $-0.128 * *$ & 1 & & & & & & & \\
\hline PALS & $-0.140 * *$ & & 1 & & & & & & \\
\hline DFDF & $0.505 * *$ & $-0.044 * *$ & $-0.073 * *$ & 1 & & & & & \\
\hline ECST & $-0.095^{* *}$ & -0.005 & $0.045 * *$ & $-0.059 * *$ & 1 & & & & \\
\hline EMTM & 0.002 & 0.004 & -0.005 & 0.015 & -0.006 & 1 & & & \\
\hline ECGR & $-0.120 * *$ & -0.007 & 0.017 & $-0.039 * *$ & 0.021 & -0.011 & 1 & & \\
\hline POTS & $-0.077 * *$ & 0.01 & -0.002 & $-0.201 * *$ & 0.009 & 0.015 & -0.011 & 1 & \\
\hline ATFD & $-0.094 * *$ & 0.01 & 0.007 & -0.027 & -0.007 & -0.007 & $0.032 *$ & 0.002 & 1 \\
\hline
\end{tabular}

** Significant correlation at the level of 0.01(two-tailed).

* Significant correlation at the level of 0.05 (two-tailed).

In addition, the absolute values of the two-way correlation coefficients between the quality of financial information, profit and loss situation, debt financing demands, the ability to raise debt financing, capital structure and growth in executive compensation do not exceed 
0.3 , which indicates that there is no significant multicollinearity between the analyzed variables.

\section{Binary Logistic Regression Analysis and Empirical Results}

The regression results obtained from this binary logistic regression model regarding whether the fair value measurement model can be chosen as the dependent variable are shown in Table 6. In it, the value of the estimated coefficient for the quality of financial information is $-0.801(\mathrm{p}=0.000<0.001)$, which implies that the quality of financial information prior to the adoption of the fair value measurement model has a negative impact on the decision of whether the fair value measurement model is chosen.

Table 6 - Binary Logistic Regression Results (made by the author)

\begin{tabular}{|c|c|c|c|c|c|}
\hline Variables & B & $\begin{array}{c}\text { Standard } \\
\text { Deviation }\end{array}$ & Wald & $\begin{array}{c}\text { Degrees of } \\
\text { Freedom }\end{array}$ & $\begin{array}{c}\text { Statistical } \\
\text { Significance }\end{array}$ \\
\hline QOFI & $-0.801^{* * *}$ & 0.188 & 18.101 & 1 & 0.000 \\
\hline PALS & $-5.698^{* * *}$ & 0.915 & 38.758 & 1 & 0.000 \\
\hline DFDF & $10.591 * * *$ & 0.779 & 184.904 & 1 & 0.000 \\
\hline ATFD & $-0.466^{* *}$ & 0.139 & 11.315 & 1 & 0.001 \\
\hline ECST & $-16.855^{* * *}$ & 1.348 & 156.266 & 1 & 0.000 \\
\hline ECGR & $-6.463^{* * *}$ & 0.576 & 125.681 & 1 & 0.000 \\
\hline EMTM & 0.087 & 0.232 & 0.141 & 1 & 0.707 \\
\hline POTS & $-0.064^{* *}$ & 0.022 & 8.35 & 1 & 0.004 \\
\hline
\end{tabular}

\begin{tabular}{|c|c|c|c|c|c|}
\hline Constants & -11.062 & 4.252 & 6.769 & 1 & 0.009 \\
\hline Omnibus Test & \multicolumn{5}{|c|}{$2119.192 * * * \quad(0.000)$} \\
\hline $\begin{array}{l}\text { Hosmer and Lemeshow } \\
\text { Tests }\end{array}$ & \multicolumn{5}{|c|}{$5.826(0.667)$} \\
\hline 2 Log likelihood & \multicolumn{5}{|c|}{522.19} \\
\hline Cox \& Snell R2 & \multicolumn{5}{|c|}{0.378} \\
\hline NagelkerkeR2 & \multicolumn{5}{|c|}{0.846} \\
\hline
\end{tabular}

The value of the estimated coefficient of the profit and loss situation of enterprises is $5.698(\mathrm{p}=0.000<0.01)$, which implies that the quality of financial information prior to the adoption of the fair value measurement model has a significant negative impact on whether the fair value measurement model would be chosen.

The value of the estimated coefficient of the debt financing demand estimate is positive and significant at the level of 0.001, which indicates that the higher the debt financing demand prior to the adoption of the fair value measurement model, the more possible it 


\section{AN EMPIRICAL STUDY ON THE MOTIVATION}

would be for the enterprise to choose the fair value measurement model. In addition, the values of the estimated coefficients on the enterprises' ability to raise debt financing, the growth rate of the total assets and the stock price are all significant at the level of 0.01, and all are with the sign of "-", which indicates that the lower the enterprises' ability to raise debt financing, the smaller the growth rate of the total assets and the lower the stock price before the adoption of the fair value measurement model for their investment properties.

Thus, the more likely they would be to choose the fair value measurement model. Besides, the value of the estimated coefficient on the tendency of earnings management is not significant in this model, which indicates that the tendency of enterprises for earnings management before they choose the fair value measurement model does not have a significant effect on whether the fair value measurement model is adopted.

\section{Empirical Results}

After further descriptive statistics and regression analysis by collating the valuation model measures of whether or not enterprises that own investment properties adopt the fair value measurement model, it can be seen that based on the empirical results, whether or not the fair value measurement model is chosen is significantly correlated with the quality of financial information, profit and loss situation, debt financing demands, ability to finance debt, executive compensation growth ratio, capital structure, and stock price prior to the adoption of the fair value measurement model.

As verified by a binary logistic regression analysis, the values of estimated coefficients of the effects of quality of financial information, profit and loss situation, debt financing demands, ability to raise debt financing, executive compensation growth ratio, capital structure and stock price are significant, which indicates that these factors are important in influencing the adoption choice of the fair value measurement model for enterprises that own investment properties.

The results of the verification of the study hypotheses presented in the previous chapter are as follows: study hypotheses H1, H2, H3, H4, H5, H6 and H8 are all supported, but the existing findings do not support H7. However this is not indicating H7 is not relevance the reason why the result is not significant may because of the scope of the sample size is not big enough.

\section{Conclusions and Implications}

Taking listed companies that had adopted the fair value model for the subsequent measurement of investment properties in the time period from 2015 to 2019 as the study subjects, the specific motivations behind choosing the subsequent measurement model for investment properties were empirically verified from the perspectives of both opportunistic motives of the enterprises executives in choosing the fair value model and improving the quality of accounting information.

The results show that some enterprises' financial officers and other executives do not agree with the value relevance and reliability of the fair value measurement model in investment properties, however, the possibility of executives choosing the fair value model for subsequent measurement for investment properties is significantly correlated with the quality of financial information, the loss of enterprise performance, the demand for debt 
financing, the ability to finance debt, the growth rate of executive compensation, the growth rate of total assets, and the stock price.

This indicates that the choice of the fair value measurement model by the enterprise executives is only for the purposes of achieving enterprise growth and the advancement of executives' interests rather than for the purposes of providing more relevant accounting information to investors.

Therefore, the standards regulators should further revise and improve the guidelines concerning investment properties, such as loosening the criteria for the application of the fair value model, developing a unified fair value measurement framework, issuing operational guidelines on fair value, improving the practicability of the application of the fair value model, etc., so as to guide enterprise executives towards a more efficiency-oriented approach in the choice of the fair value model.

The regulator should also strengthen the supervision of changes in the subsequent measurement model of investment properties, such as reviewing the rationality of changes in the subsequent measurement model of investment properties by enterprises in detail and requiring enterprises to engage certified public accountants to conduct special audits on the changes in the subsequent measurement model of investment properties, so as to curb the opportunistic behavior of enterprise executives in choosing the fair model.

\section{References}

Aleszczyk, A., De George, E.T. \& Ertan, A. (2020). Debt financing and balance-sheet Collateral: Evidence from fair-value adjustments. Available at SSRN 3032580.

Ashwag, D. (2017). Research on the correlation between fair value level disclosure and accounting information risk. Research on Financial and Economic Issues, 12, 83-89.

Ball, R. (2006). International financial reporting standards(IFRS): pros and cons for investors. Accounting and Business Research, 36 (1), 5-27.

Dai, J.-J., Ji, X. \& Zhang, Q. (2011). Financial Influence and Determinants of Transfer of Investment Property Measurement Model; A Case of Shanghai Shimao Incorporated Company. Accounting and Economics Research, 8, 22-29.

Eliwa, Y., Haslam, J. \& Abraham, S. (2016). The association between earnings quality and the cost of equity capital: Evidence from the UK. International Review of Financial Analysis, 48, 125-139.

Fargher, N. \& Zhang, J. Z. (2014). Changes in the measurement of fair value:Implications for accounting earnings. Accounting forum, 38(3), 184-199.

Hou, X. \& Guo, Y. (2013). Analysis on Influencing Factors of fair value measurement mode selection of investment real estate. Finance and Accounting, 02, 64-65.

Qiang, X. (2007). The effects of contracting, litigation, regulation and tax costs on conditional and unconditional conservatism: cross. The Accounting Review, 82(3), 759 - 796.

Quagli, A. \& Avallone, F. (2010). Fair value or cost model? Drivers of choice for IAS 40 in the real estate industry. European Accounting Review, 19(3), 461-493.

Walid, E. \& Bondar.G.M. (2017). Alternative accounting methods: theory and evidence. The Accounting Review, 71 (3), 397- 418.

Wang, F. \& Cheng, F. (2014). Motivations to Choose Fair Value Measurement Model for Investment Properties. The Theory and Practice of Finance and Economics, (3), 14. 


\section{AN EMPIRICAL STUDY ON THE MOTIVATION}

Xiaohui, Z. (2015). Fair value measurement of investment property in listed companies: influence factors and economic consequences. Central University of Finances and Economics.

Yajun, L. \& Xiaohong, H. (2012). Why is the fair value measurement mode not widely adopted for investment real estate. Finance and Accounting Monthly, 3, 67-69.

Ying, C. (2010). Selection of fair value measurement mode of investment real estate. Research on Financial and Economic, 6, 102-109.

Yinghe, D. (2018). Impact of Fair Value Measurement on the Financial Information Quality of Enterprise Assets. Journal of Huaihai Institute of Technology (Humanities \& Social Sciences Edition), 1, 32.

Yongze L. \& Yan, M. (2011). On the Application Dilemma of Fair Value Measurement Model for Real Estate Investment and the Coutermeasures. Contemporary Finance \& Economics, 8, 102109.

Paper submitted

Paper accepted for publishing

Paper published online
11 October 2021

14 November 2021

31 January 2022 